\title{
A large aspergilloma
}

\author{
Marcello Migliore, ${ }^{1}$ Mariapia Gangemi, ${ }^{1}$ Damiano Calvo, ${ }^{1}$ Stefano Palmucci ${ }^{2}$
}

${ }^{1}$ Section of Thoracic Surgery, Department of Surgery, Policlinico Hospital, University of Catania, Catania, Italy ${ }^{2}$ Department of Radiology, University of Catania, Italy

\section{Correspondence to} Professor Marcello Migliore, mmiglior@unict.it

\section{DESCRIPTION}

A 42-year-old man presented with productive cough, haemoptysis, night sweating, temperature $39^{\circ} \mathrm{C}$, asthenia and weight loss of $35 \mathrm{~kg}$ in 12 months. He had a 25 -year history of smoking (40 cigarettes/day) and alcoholism. Laboratory tests showed normochromic normocytic anaemia (haemoglobin $8.8 \mathrm{~g} / \mathrm{dL}$, red blood cell $2.72 \times 10^{6}$ / mmc, and mean corpuscular volume 100), neutrophilic leucocytosis and white cell count $\left.1778 \times 10^{3} / \mathrm{mmc}\right)$. Chest CT scan revealed an excavated lesion in the apico-dorsal segment of the left upper lobe $(65 \times 70 \mathrm{~mm})$ with solid vegetation inside, delimitated by a thick wall with polylobate

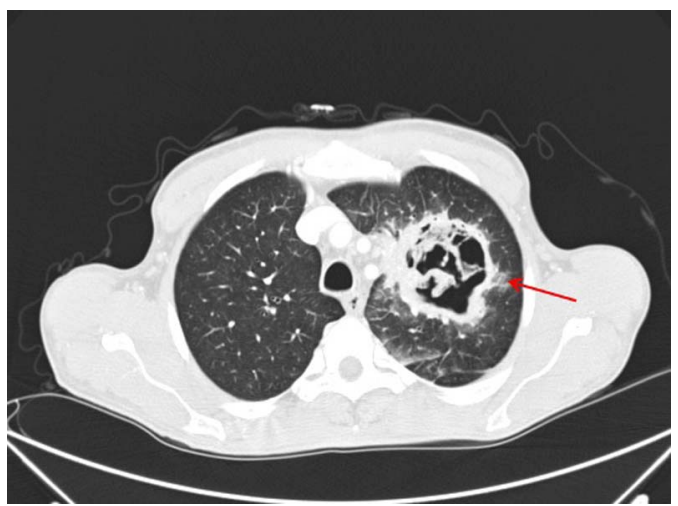

Figure 1 Axial chest CT. A large excavated lesion in the apico-dorsal segment of left upper lobe $(65 \times 70 \mathrm{~mm})$ bounded by thick wall with poly-lobed margins; the arrow indicates the 'halo' sign. edges, and the suggestive presence of 'halo sign' (figure 1). The solid vegetation was characteristically movable changing the body position (figure 2 ). Video bronchoscopy showed the presence of purulent secretions from the left upper lobe bronchus with easily bleeding mucosae. Results of microbiological examination were normal. Although the bronchial biopsy showed metaplastic and thickened plate epithelium, focal parakeratosis, mild dysplasia and leucocyte exocytosis, the diagnosis of pulmonary aspergilloma (PA) was highly suspected. The patient underwent left upper pulmonary lobectomy with mediastinal lymphadenectomy. The final histology confirmed the presence of a large aspergilloma (figure $3 \mathrm{~A}-\mathrm{C}$ ). The patient was discharged on the sixth postoperative day. The patient is asymptomatic at 16 months of follow-up.

The diagnosis of PA is challenging, and a multidisciplinary approach as for other diseases is encouraged. ${ }^{1}$ Although the bronchoscopy was unable to identify the causative agent in our patient, generally it plays a central role not only for the diagnosis of PA but also for therapeutic interventions. $^{2}$

A classic radiographic appearance of PA is a cavity containing a solid, round and often mobile intracavitary fungus ball. Another CT characteristic is the presence of the halo sign which refers to a zone of ground-glass attenuation surrounding a pulmonary nodule or mass on CT images, and may be the first evidence of pulmonary fungal infection. $^{3}{ }^{4}$ In conclusion, the contemporary presence of both these CT findings make the diagnosis of PA especially truthful.

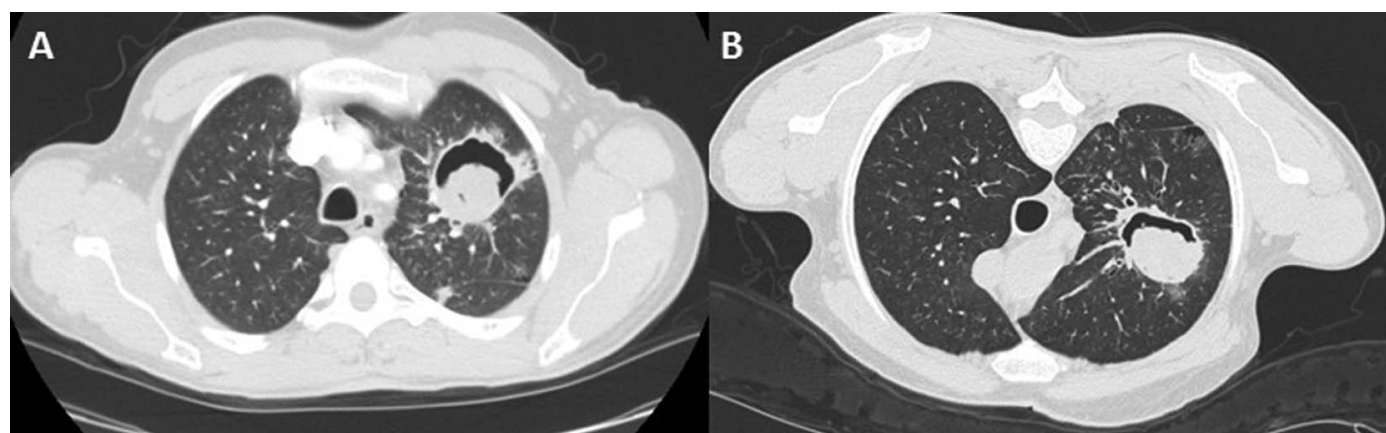

Figure 2 Axial chest $\mathrm{CT}$ in supine (A) and prone (B) position. The solid vegetation is movable changing the body position.

To cite: Migliore $\mathrm{M}$ 

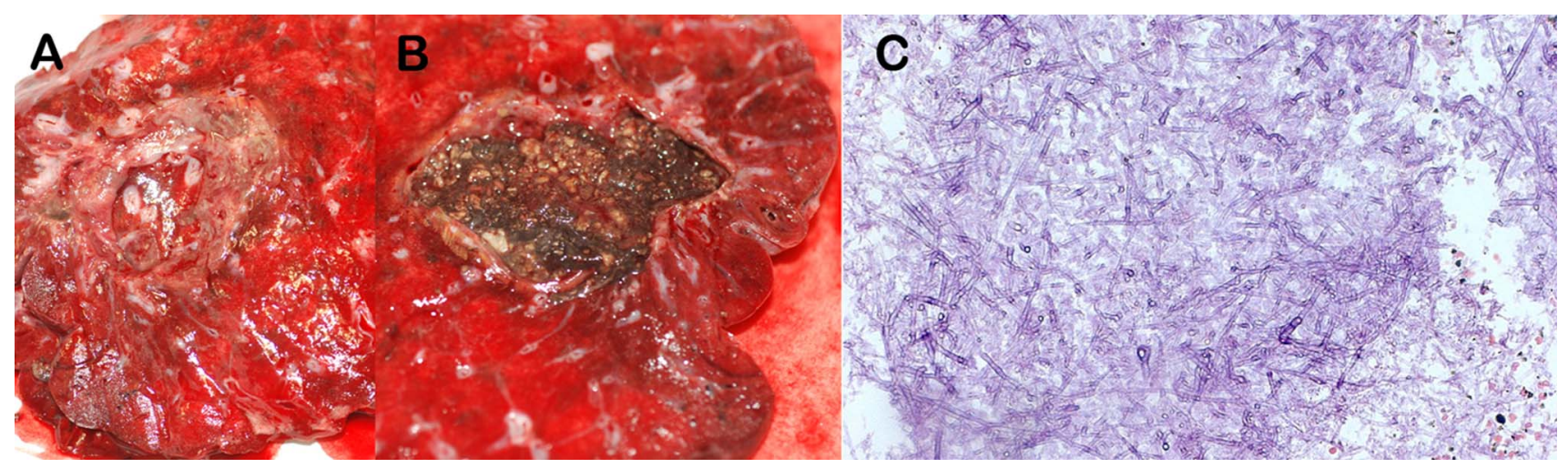

Figure 3 (A and B) Macroscopic specimen; and (C) histopathological examination with H\&E. (A) Perilesional fibrosis; (B) the presence of cavities with necrotic-purulent content; and (C) fungal hyphae and spore.

\section{Learning points}

- Although not always evident, the presence of a mobile vegetation inside a lung cavity is highly suggestive of pulmonary aspergilloma.

- CT halo sign is also highly suggestive of pulmonary fungal infection.

- The contemporary presence of both these CT findings makes the diagnosis of pulmonary aspergilloma very accurate.
Competing interests None.

Patient consent Obtained.

Provenance and peer review Not commissioned; externally peer reviewed.

\section{REFERENCES}

1 Migliore M, Vecchio I, Rampello L, et al. Multidisciplinary approach of non-thymomatous myasthenia gravis. Acta Medica Mediterranea 2012;28:211-13.

2 Stather DR, Tremblay A, MacEachern P, et al. Bronchoscopic removal of a large intracavitary pulmonary aspergilloma. Chest 2013;143:238-41.

3 Pinto PS. The CT halo sign. Radiology 2004;230:109-10.

4 Soubani AO, Chandrasekar PH. The clinical spectrum of pulmonary aspergillosis. Chest 2002;121:1988-99.

Copyright 2013 BMJ Publishing Group. All rights reserved. For permission to reuse any of this content visit

http://group.bmj.com/group/rights-licensing/permissions.

BMJ Case Report Fellows may re-use this article for personal use and teaching without any further permission.

Become a Fellow of BMJ Case Reports today and you can:

- Submit as many cases as you like

- Enjoy fast sympathetic peer review and rapid publication of accepted articles

- Access all the published articles

- Re-use any of the published material for personal use and teaching without further permission

For information on Institutional Fellowships contact consortiasales@bmjgroup.com

Visit casereports.bmj.com for more articles like this and to become a Fellow 